\title{
Apocrine hidrocystoma with telangienctasia: an atypical finding
}

\author{
Vempuluru Sai Vijitha, ${ }^{1}$ Anasua Ganguly Kapoor, ${ }^{1}$ Dilip K Mishra ${ }^{2}$
}

'LV Prasad Eye Institute, Vijayawada, Andhra Pradesh, India

${ }^{2}$ LV Prasad Eye Institute, Hyderabad, Telangana, India

\section{Correspondence to}

Dr Anasua Ganguly Kapoor, anasua21@yahoo.com

Accepted 17 August 2019
Check for updates

(C) BMJ Publishing Group Limited 2019. No commercial re-use. See rights and permissions. Published by BMJ.

To cite: Vijitha VS,
Kapoor AG, Mishra DK. BMJ
Case Rep 2019;12:e231572.
doi:10.1136/bcr-2019-
231572

\section{DESCRIPTION}

Apocrine hidrocystoma of the eyelid, also known as apocrine cystadenoma or sudoriferous cyst, is a retention cyst of the glands of Moll at the eyelid margin. Commonly seen in adults of middle age, it has a predilection for the medial canthus. They may be isolated or occur in clusters as a part of Schopf-Schulz-Passarge syndrome. It usually appears a smooth or multiloculated cystic lesion in the periocular region. Size is variable from 1 to $10 \mathrm{~mm}$, and due to the presence of a bluish hue, it can be mistaken for a melanoma or blue nevus. ${ }^{1-3}$ Microscopically, a cystic lesion lined by double layer of cells with a clear lumen is characteristic of apocrine hidrocystoma. The outer layer is formed by flattened myoepithelial cells, and the inner layer has apical snouts, which project into the lumen. Complete surgical excision is recommended, and the prognosis is excellent. ${ }^{1}$

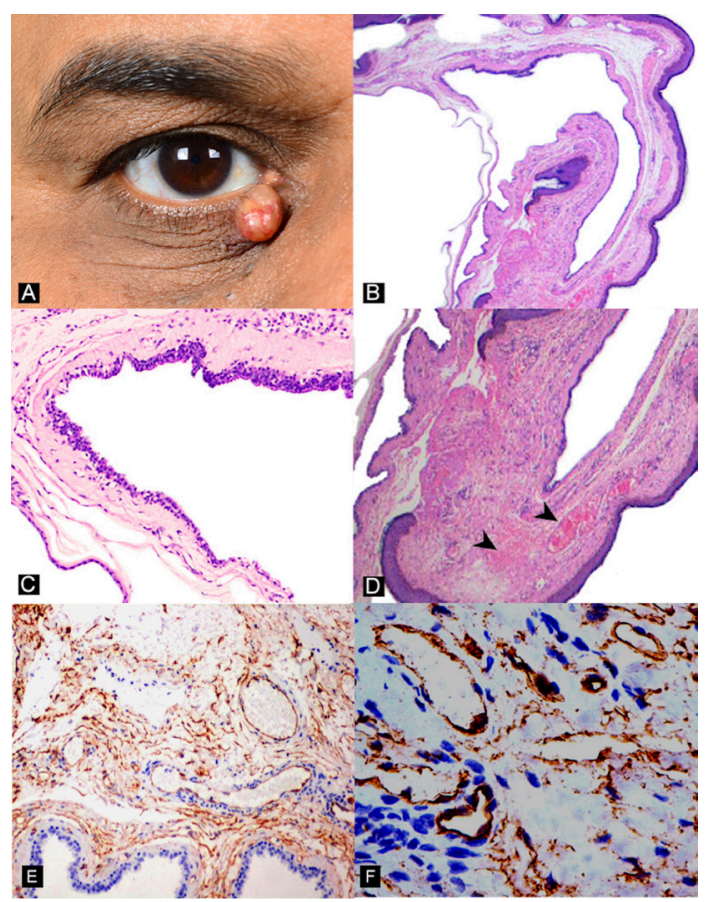

Figure 1 (A) Clinical image of the eyelid margin cyst involving the peripunctal region of the lower eyelid with telangiectatic surface vessels and multiple lobules within the substance of the cyst; (B) photomicrograph showing a cystic space (H\&E 20x); (C) photomicrograph of the luminal wall of the cyst lined by columnar to cuboidal epithelium with focal areas of multilayering and apical snouts (H\&E 100x); (D) photomicrograph showing congested blood vessel surrounding the cyst wall ( $\mathrm{H} \& \mathrm{E}$ $40 x)$. (E) Expression of CD34 in endothelial cells of blood vessels (immune stain 100x). (F) Expression of CD34 in endothelial cells of blood vessels (immune stain 400x).
This tumour presented as a painless lobulated cystic lesion with multiple telangiectatic vessels over the surface at the medial aspect of the lower eyelid margin in a 44-year-old man (figure 1A). Histopathology revealed keratinised stratified squamous lining with cystic spaces within the stroma. The luminal wall of the cyst was lined by single to multilayered columnar to cuboidal cells with the characteristic 'apical snout' projecting towards the lumen of the cyst (figure 1B,C). In addition, multiple telangiectatic vessels were noted, which is not a typical feature of this tumour (figure 1D). These were filled with blood and also expressed CD34 in endothelial cells, confirming them to be blood vessels (figure 1E,F). Telangiectasia are not known to occur in hidradenomas, and we here describe this rare finding noted in this uncommon tumour, which can raise the suspicion of a malignancy on clinical examination.

\section{Patient's perspective}

I had visited ophthalmologists who had diagnosed me to have eyelid cancer. However, at my last visit with the author, I was told that it is most likely a noncancerous tumour with an atypical feature. The same was confirmed on biopsy after surgical removal of the tumour. Now I am doing fine. I understand that this manuscript will make the readers aware of this atypical presentation of this uncommon tumour and hence prevent misdiagnosis.

\section{Learning points}

- Apocrine hidrocystomas are rare periocular tumours of adnexal origin, which may mimic eyelid malignancies.

- Telangiectasia although not typical may occur in apocrine hidrocystomas.

- Characteristic histopathology includes a cyst lined by epithelium, which forms 'apical snouts'.

Contributors VSV is responsible for collection of data and drafting the manuscript. AGK is responsible for managing the patient, formulation and editing of the manuscript. DKM is responsible for managing the patient and editing the manuscript.

Funding The authors have not declared a specific grant for this research from any funding agency in the public, commercial or not-for-profit sectors.

Competing interests None declared.

Patient consent for publication Obtained.

Provenance and peer review Not commissioned; externally peer reviewed. 


\section{Images in...}

\section{REFERENCES}

1 Shields JA, Shields CL. Eyelid, conjunctival and orbital tumors: an atlas and textbook. Philadelphia: Lippincott Williams \& Wilkins, 2017.
2 Smith RJ, Kuo IC, Reviglio VE. Multiple apocrine hidrocystomas of the eyelids. Orbit 2012;31:140-2.

3 Smith JD, Chernosky ME H. Hidrocystomas. Arch Dermatol 1973;108:676-8.

Copyright 2019 BMJ Publishing Group. All rights reserved. For permission to reuse any of this content visit https://www.bmj.com/company/products-services/rights-and-licensing/permissions/

BMJ Case Report Fellows may re-use this article for personal use and teaching without any further permission.

Become a Fellow of BMJ Case Reports today and you can:

- Submit as many cases as you like

- Enjoy fast sympathetic peer review and rapid publication of accepted articles

Access all the published articles

Re-use any of the published material for personal use and teaching without further permission

Customer Service

If you have any further queries about your subscription, please contact our customer services team on +44 (0) 2071111105 or via email at support@bmj.com.

Visit casereports.bmj.com for more articles like this and to become a Fellow 